\title{
Urška Strle
}

\section{Carlo Spartaco Capogreco: Fašistična taborišča. Internacije civilistov v fašistični Italiji (1940-1943)}

\author{
Ljubljana: Publicistično društvo ZAK, prev. Nevenka Troha, 2011, 331 strani
}

Ob izteku leta 2011 smo v slovenščino dobili prevod monografije izpod peresa italijanskega raziskovalca Carla Spartaca Capogreca - naslov izvirnika I campi del Duce: L'internamento civile nell'Italia fascista (1940-1943) -, ki je leta 2004 izšla pri ugledni italijanski založbi Einaudi; po izidu je bila šest mesecev na lestvici najbolj prodajanih knjig in je čez dve leti doživela ponatis. Zgodovinarki dr. Nevenki Troha, tudi sicer odlični poznavalki italijanskega fašizma, ki je avtorju s svojimi komentarji pomagala pri nastanku monografije, se velja zahvaliti za konsistenten prevod te visokoinformativne, analitične in za slovenski prostor nedvomno referenčne knjige. Pred izidom omenjene monografije so italijanščine nevešči bralci lahko v roke vzeli Capogrecovo delo v hrvaškem prevodu, ki je izšel že dve leti po izidu izvirnika; Capogrecu je takratni hrvaški predsednik Stjepan Mesić zaradi razkrivanja dejstev o fašističnih vojnih zločinih podelil državno odlikovanje. Promocija slovenskega prevoda leta 2013 je sovpadla s 70-letnico kapitulacije Italije in posledičnega razpusta fašističnih taborišč, kar utegne oploditi razpravo o tematiki, ki - prekrita $z$ drugimi poglavji iz vojnega časa - v širši javnosti ni bila primerno prepoznavna.

Monografija je razdeljena na štiri poglavja. V prvem avtor pojasnjuje potrebo po redefiniciji tipografije fašističnih taborišč, ki navadno sledi uveljavljeni tipografiji nacističnih taborišč. Italijanska fašistična taborišča izkazujejo odvisnost od italijanskih družbeno-političnih specifik. Tudi razlikovanje med tipi taborišč, ki so Capogrecov avtorski prispevek $\mathrm{k}$ primernejšemu poimenovanju, temelji na prepričanju, da izraz koncentracijsko taborišče, ki je zlagoma prerasel v zamegljeno nadpomenko za vse oblike množičnega zapiranja civilistov, vsebuje preveč protislovij, da bi omogočil konsistentno historiografsko analizo raznovrstnega in dinamičnega internacijskega mehanizma. V tem poglavju avtor med drugim uvaja skovanko vzporedne internacije civilistov, ki je zadevala pravno neosnovano internacijo (zlasti) slovanskega prebivalstva. Delitev internacijskega mehanizma na pravno osnovane in pravno neosnovane internacije je po Capogrecovem mnenju ključna in spremlja celotno strukturo knjige. 
V drugem poglavju predstavi ustroj administrativnega korpusa, na katerem je navadno temeljila internacija civilistov. Pravno utemeljena internacija civilistov je bila v pristojnosti notranjega ministrstva; zajemala je predvsem policijsko sumljive osebe $\mathrm{z}$ italijanskim državljanstvom, zlasti politične nasprotnike, ter v Italiji začasno bivajoče državljane držav, ki so bili v vojni z Italijo. Množična pravno neosnovana oziroma vzporedna internacija civilistov pa je potekala $v$ neposredni režiji vojaških oblasti v času vojne okupacije. To poglavje $\mathrm{v}$ določeni meri pojasnjuje nepotrebno težke bivanjske razmere v t. i. taboriščih za Slovane, v katerih je prišlo do zapletov in neusklajenosti tudi zaradi medinstitucionalnih konfliktov glede pristojnosti.

Tretje poglavje obravnava skupine ljudi, ki so bile najbolj izpostavljene internaciji, hkrati pa na podlagi dostopnih dokumentov kontekstualizira direktive za internacijo, ki so se nanašale na različne podskupine italijanskih in tujih državljanov. Med njimi s konkretnimi primeri predstavi predvsem potencialne in realne politične nasprotnike iz vrst protifašistov (predvsem anarhistov in komunistov), državljane tistih držav, s katerimi je bila Italija v vojni, tuje in domače pripadnike judovske in romske skupnosti, ljudi brez državljanstva ter alogene oziroma pripadnike narodnih manjšin, med katerimi je bila tudi slovenska. Po sicer nelegalni priključitvi Ljubljanske pokrajine k Italiji maja 1941 bi med alogene pogojno lahko šteli tudi tamkajšnje neitalijanske prebivalce - ti so bili na koncu deležni vzporedne internacije, čeprav bi jim morali po zakonu priznati vsaj status »sovražnih tujcev«.

Četrto poglavje skozi prizmo razpoložljive dokumentacije in izbranih pričevanj rekonstruira in kontekstualizira življenje $\mathrm{v}$ taboriščih, konceptualno pa je zopet razdeljeno na pravno osnovane in vzporedne internacije; $\mathrm{v}$ t. i. taboriščih za Slovane so bili življenjski pogoji bistveno slabši od tistih za internirance na podlagi pravno osnovanih internacij. Posebna pozornost je posvečena poskusom pomoči internirancem, ki je prikazana skozi delovanje Rdečega križa in RKC. Oblikam samopomoči med interniranci samimi, solidarnostnemu odrekanju poslanih paketov v skupen fond, Capogreco ni posvečal pozornosti.

Sledi stostranski seznam taborišč s krajšimi opisi delovanja in namembnosti, opremljen s podatki o uradnih zabeležkah o številu internirancev in relevantnimi arhivskimi viri. Iz tega dela knjige je razvidno, kako je internacijski sistem pogosto deloval improvizorično in posledično neučinkovito, predvsem na škodo internirancev. Posebnost tega dela knjige je v prikazovanju detajlov, spričo katerih je razvidno, da so se zaradi raznolikih internih pogojev (vodstvo, lokacija, število internirancev ipd.) taborišča med seboj precej razlikovala; posebno kritične so bile razmere v sicer največjem taborišču Kampor na otoku Rabu, ki je bilo neposredno podrejeno II. armadi italijanske vojske. Izjemno visoka umrljivost rabskih internirancev - ki se je nadaljevala 
po premestitvi internirancev v druga taborišča in tudi po vrnitvi domov - je rabsko taborišče umestila kot »najhujše med vsemi italijanskimi taborišči med drugo svetovno vojno«. Po številu internirancev - ocene se gibljejo okoli 15.000 ljudi vseh starosti in obeh spolov, med njimi pa so prevladovali Slovenci - je bilo rabsko taborišče hkrati eno od največjih taborišč po številu Slovencev v času druge svetovne vojne.

Capogreco se je raziskave o Ducejevih taboriščih skušal lotiti celostno, s pomočjo bogatih in raznovrstnih arhivskih dokumentov, obsežne strokovne literature, materialnih dokazov in ilustrativne moči pričevanj. Gradivo, s pomočjo katerega je avtor črpal snov za pojasnitev ne le stanja v taboriščih, ampak predvsem konteksta organizacije in delovanja taborišč v vojnem času, je po obsegu neenakomerno, različno dostopno in precej razdrobljeno. Prav mapiranje, kategorizacija in analiza več kot 60 taborišč različnih tipov in namembnosti lahko štejemo kot izjemen dosežek knjige. Monografija ima namreč ambicijo celostnega orisa fašističnega taboriščniškega sistema med drugo svetovno vojno, ki je bil doslej predstavljen predvsem v parcialnih raziskavah in osvetlitvah zgolj določenih internacijskih lokacij. To delo je bilo zahtevno in v več primerih filigramsko, saj za določene taboriščniške lokacije avtor ni našel nobenega arhivskega gradiva; nekaj pozabljenih lokacij je razkril s pomočjo pričevanj preživelih internirancev.

$\mathrm{Na}$ ta način je Capogreco skušal zapolniti spominske luknje o tovrstni genocidni plati fašističnega obdobja med drugo svetovno vojno, na katere so v zadnjih desetletjih opozarjali, kot je razvidno iz navedene bibliografije, presenetljivo številčni - čeravno za laično italijansko publiko očitno ne dovolj prodorni - italijanski zgodovinarji. Siva lisa zgodovinopisne obravnave taborišč je bila, kot v Uvodu svoje knjige ugotavlja avtor, pogojena s tem, da je bila večina pozornosti usmerjena »na politično in vojaško zgodovino odporništva«, kar je manj prijetnejšim temam puščalo razmeroma malo prostora. Tudi izpostavljanje bolj notoričnih vidikov nacističnih zločinov v italijanski javnosti je po mnenju avtorja služilo kot »alibi za to, da so se pozabili lastni«. Od leta 1973, ko je bil zaradi objave svoje raziskave z naslovom I genocidio cirenaico e la storiografia coloniale izpostavljen žalitvam in obtožen "protiitalijanskega sektaškega predsodka « Giorgio Rochat, pa do škandala iz februarja 2012, ko so predavanje videmske zgodovinarke Alessandre Kersevan na univerzi v Veroni skušali onemogočiti tudi z rektorske instance, precej velika stopnja nelagodja določenih italijanskih krogov v zvezi s to temo ni upadla. To velja tudi za nekatere prezentacije v množičnih medijih, ki zločine italijanskih fašističnih oblasti pripisujejo kar nacistom oziroma »slovanskim Titoistom«. Capogrecova knjiga, ki je zaradi nizke cene in berljivega sloga postala dostopna širšemu krogu italijanskih bralcev, je gotovo korak k preseganju takšnih zavajanj. 
V spominu italijanskega in širšega mednarodnega prostora se je italijanski fašistični režim vsidral kot razmeroma blaga različica totalitarnih režimov; zlasti pri asociacijah na totalitarni internacijski sistem, kamor se denimo med prvimi uvrstijo Hitlerjeva koncentracijska taborišča ali Stalinovi gulagi, so Mussolinijeva taborišča navadno izostala. V strokovni javnosti velik del odgovornosti za to po Capogrecovem mnenju nosita avtorja visokoreferenčnih del Hannah Arendt (Izvori totalitarizma) in Andrzej J. Kamiński (Konzentrazionslager 1896 bis heute. Eine Analyse), ki sta v svojih obravnavah fašistični sistem taborišč predstavila le obrobno oziroma sploh ne. Splošna prepoznavnost nacističnih taborišč in gulagov se je širila $\mathrm{z}$ bogato filmsko in knjižno produkcijo, medtem ko o fašističnih taboriščih ne pomnim niti enega mednarodno prepoznavnega filma s kritično ostjo proti fašizmu - z izjemo odmevnega, a hkrati tudi bizarnega, težko gledljivega in širši javnosti tudi težje razumljivega Passolinijevega filma 120 dni Sodome, postavljenega v obdobje t. i. Salojske republike. Poleg tega v kontekstu diplomatskih smernic in iskanja svetovnega političnega ravnotežja fašistični režim ni bil izpostavljen nobenim mednarodnim obtožnicam, čeprav je bila OZN predložena obsežna dokumentacija o vojnih zločinih fašističnih oblasti - tudi o deportacijah in internacijah civilnega prebivalstva.

Kljub angažmaju slovenskih zgodovinarjev tragična epizoda medvojnih fašističnih internacij danes predstavlja razmeroma majhno v(r)ednost v kolektivnem spominu Slovencev, četudi je bilo samo iz Ljubljanske pokrajine v internacijo odpeljanih skoraj 30.000 civilistov, ki so na Rabu, v Gonarsu, Monigu, Padovi, Renicciju, Viscu in drugih, manj znanih taboriščih životarili v nečloveških razmerah. Še manj so ovrednotene internacije primorskih Slovencev, ki so bili izpostavljeni ostrini fašističnega režima $\mathrm{v}$ celotnem obdobju med obema vojnama in tudi med vojno. Bogata pričevanjska in literarna zapuščina, ki je začela nastajati neposredno po taboriščniški izkušnji in nastaja še danes, zaenkrat še ni bila deležna sistematičnega historiografskega ovrednotenja, čeprav razkriva številne perspektive, ki jih arhivski viri ne zmorejo. Iz pogleda od spodaj je možno ne nazadnje razbrati tudi to, da so bile internacije tesno povezane $z$ NOB in da so na kapilarni ravni interniranci aktivno načenjali moči fašistične alianse. Prav zaradi neizčrpanosti teme v slovenskem zgodovinopisju pomeni Capogrecova knjiga, ki postavlja slovensko taboriščniško izkušnjo $\mathrm{v}$ celosten okvir fašističnih internacij, pomembno dopolnilo za razumevanje okoliščin slovenskega prebivalstva $\mathrm{v}$ fašističnem internacijskem mehanizmu in pod okupacijo nasploh. 